Токарева Ольга Николаевна

учитель

КОУ «Адаптивная школа №12»

студентка

ФГБОУ ВО «Омский государственный педагогический университет»

г. Омск, Омская область Научный руководитель

Шерешик Наталья Николаевна канд. психол. наук, доцент ФГБОУ ВО «Омский государственный педагогический университет» г. Омск, Омская область

DOI $10.21661 / r-519238$

\title{
ОСНОВНОЕ СОДЕРЖАНИЕ РАБОТЫ КЛУБОВ ПСИХОЛОГО-ПЕДАГОГИЧЕСКОГО СОПРОВОЖДЕНИЯ РОДИТЕЛЕЙ, ВОСПИТЫВАЮЩИХ ДЕТЕЙ С ОГРАНИЧЕННЫМИ ВОЗМОЖНОСТЯМИ ЗДОРОВЬЯ
}

Аннотация: в статье обосновывается идея создания психологических клубов для родителей, воспитывающих детей с ограниченными возможностями здоровья, которые нуждаются в психолого-педагогической помощи. Значительное внимание уделяется повышению родительской компетентности в вопросах воспитания, развития, сочиальной адаптащии «особых» детей, посредством психолого-педагогического просвещения; привлечение родителей к сотрудничеству в плане единых подходов к воспитанию и обучению ребёнка.

Ключевые слова: комплексный подход, родительский клуб, психолого-педагогическое сопровождение, психологический клуб.

В настоящее время общество требует от науки и практики изучения семей, имеющих детей с ограниченными возможностями здоровья, и разработки мер 
помощи такой семье. Такие дети, в силу имеющихся различных симптомов, не могут быть социализированы в общество сами по себе, отдельно от того микросоциума, которым они окружены с самого рождения. Потому так важна интеграция в общество всей семьи ребенка с ограниченными возможностями здоровья. Родители, воспитывающие детей с ограниченными возможностями здоровья, нуждаются в психолого-педагогическом сопровождении, что является необходимой частью комплексного сопровождения, которое оказывает впоследствии влияние на развитие ребёнка и его адаптацию в социум.

Сопровождение родителей ребенка с ограниченными возможностями здоровья - деятельность, активизирующая коррекционно-развивающие ресурсы семьи, обеспечивающая эффективность ее функционирования [3].

Комплексный подход в осуществлении психологической поддержки семьям, в которых воспитываются дети с ограниченными возможностями здоровья, позволяет оптимизировать внутрисемейную атмосферу, гармонизировать детско-родительские, родительско-детские, супружеские и межличностные взаимоотношения и, следовательно, оказать дифференциальную и адресную помощь проблемным детям.

На наш взгляд, с целью создания и укрепления отношений между родителями, воспитывающими детей с ограниченными возможностями здоровья, и родителями, воспитывающими детей с условно нормативным развитием, эффективным станет создание психологических клубов для родителей.

Такие клубы охватывают семьи, воспитывающие детей с особенностями в развитии, которые сталкиваются со специфическими проблемами и испытывают трудности в их разрешении. Как правило, это тревожная психологическая атмосфера в семье, некомпетентность родителей по вопросам воспитания и развития ребёнка, искажение контактов в окружающем социуме, и, как следствие, отсутствие поддержки со стороны социума. Поэтому целью деятельности родительских клубов является повышение родительской компетентности в вопросах воспитания, развития, социальной адаптации «особых» детей, посредством 
психолого-педагогического просвещения; привлечение родителей к сотрудничеству в плане единых подходов к воспитанию и обучению ребёнка.

Основными формами работы с родителями являются обучающие занятия; занятия в сенсорной комнате; мастер-классы; сеансы релаксации; лектории; совместные игровые занятия родителей с детьми; круглые столы; встречи с интересными людьми, специалистами разных областей, представителями общественных организаций; психологические консультации для родителей; тренинги детскородительских отношений; совместные праздники и другие.

Важной составляющей деятельности клуба является создание атмосферы принятия и признания, чувство взаимного участия, взаимной ответственности, поддержки и безопасности, а главное - безоценочное восприятие и отношение. Это достигается включением в программу встреч психологических приемов и техник психологической релаксации, визуализации, арт-терапии, телесно-ориентированных упражнений, которые способствуют снижению тревожности и формированию дальнейшей мотивации и активности родителей.

Для эффективной работы клубов необходимо создание маршрута сопровождения каждой семьи с ребенком с ограниченными возможностями здоровья. Этому способствуют следующие мероприятия:

1. Совершенствование нормативно-правовой базы коррекционно-развивающего обучения с учетом индивидуальных потребностей и возможностей детей с нарушениями психофизического развития. В этом процессе должны участвовать специалисты: педагог-психолог, учитель-логопед (дефектолог, олигофренопедагог), администрация и специалист по физической реабилитации образовательного учреждения.

2. Создание банка данных о детях с ограниченными возможностями здоровья, обучающихся образовательного учреждении.

3. Мониторинг потребностей родителей с помощью индивидуальных бесед, анкетирования и тестирования [1]. 
Индивидуальный маршрут сопровождения семьи с ребенком с ограниченными возможностями здоровья должен включать в себя:

а) план работы всех специалистов, работающих с семьей;

б) результаты контрольных срезов диагностики семьи с ребенком с ограниченными возможностями здоровья в начале работы и планируемые (предполагаемые) показатели;

в) направления и программы коррекционной и развивающей работы в разрезе каждого специалиста, работающего с семьей;

г) направления и мероприятия, направленные на воспитание и социализацию ребенка с ограниченными возможностями здоровья [4].

Рассмотрим основные этапы в модели сопровождения в условиях психологических клубов для родителей.

1. Этап знакомства. Может быть заочным (педагоги и специалисты учреждения изучают материалы личного дела ребенка, родителям предлагается тоже познакомиться с работниками учреждения) и очным (происходит на первом родительском собрании).

2. Просвещение. Информирование и обсуждение с родителями задач и содержания коррекционно-образовательной работы. Оформление различных стендов, где в доступной для родителей форме предлагается информация: списки литературы, выдержки из научных статей, рекомендации специалистов и т. д.

3. Наглядное обучение родителей. Открытые занятия специалистов и педагогов, праздники, утренники и другие общие мероприятия образовательного и учреждения играют ведущую роль в обучении родителей.

4. Консультирование. Проводится по запросам родителей. Предусматривает адресную помощь родителям по вопросам коррекции, обучения, воспитания, социализации, организации в семье коррекционно-развивающей среды.

5. Мониторинг. Анкетирование и опросы проводятся по планам администрации, дефектологов, логопедов, психологов, воспитателей и по мере необходимости. 
6. Перспектива развития ребенка. Задача учителя-дефектолога - помочь родителям увидеть перспективу в развитии ребенка: программ основного и дополнительного образования, возможности выбора профессии.

7. Рефлексия. Этап рефлексии помогает родителям и педагогам оценить успешность проведённой работы, проанализировать результаты, исправить ошибки [2].

Занятия родительского клуба проводятся примерно 1 раз в месяц. Продолжительность и время проведения одного занятия 1-1,5 часа. Основной состав группы постоянный, это позволит родителям лучше осознать предлагаемый материал и замотивировать родителей на практическое использование знаний в обучении и воспитании детей в домашних условиях.

Таким образом, психолого-педагогическая помощь родителям, воспитывающим детей с ограниченными возможностями здоровья, может осуществляться в процессе включения семей в работу психологических клубов.

\section{Список литературь}

1. Воронцова Т.Н. Сопровождение семьи ребенка с ОВЗ как проблема специального (дефектологического) образования / Т.Н. Воронцова // Студенческий: электрон. научн. журн. - 2018. - № 23(43) [Электронный ресурс]. - Режим доступа: https://sibac.info/journal/student/43/124905 (дата обращения: 14.03.2019).

2. Пазухина С.В. Психолого-педагогическое сопровождение родителей детей с ограниченными возможностями здоровья / С.В. Пазухина, 3.Н. Калинина, Е.В. Декина // Гуманитарные науки (Ялта). - 2018. - № 2 (42). - С. 128-136.

3. Психолого-педагогическое сопровождение семей, имеющих детей с OB3 [Электронный ресурс]. - Режим доступа: http://5psy.ru/obrazovanie/psihologopedagogicheskoe-soprovojdenie-semei-imeyuschih-detei-s-ovz.html (дата обращения: 14.03.2019).

4. Стругова В.Г. Социально-педагогическое сопровождение семьи ребенка с ограниченными возможностями здоровья в условиях реабилитационного центра / В.Г. Стругова, О.Б. Колесникова // Материалы Всероссийской научно-практической конференции «Наука и социум». - 2017. - №3. - С.124-130. 
5. Старшова Д. И. Психолого-педагогическое сопровождение родителей, воспитывающих детей с ограниченными возможностями здоровья / Д.И. Старшова // Молодой ученый. - 2019. - №43. - С. 219-221 [Электронный ресурс]. Режим доступа: https://moluch.ru/archive/281/63303/ (дата обращения: 27.11.2019). 